\title{
АНАЛІЗ ЗМІН ІНСТИТУЦЙНОГО МЕХАНІЗМУ ОПОДАТКУВАННЯ ФІЗИЧНИХ ТА ЮРИДИЧНИХ ОСІБ В УКРАЇНІ
}

\author{
АНАЛИЗ ИЗМЕНЕНИЙ МЕХАНИЗМА НАЛОГООБЛОЖЕНИЯ ФИЗИЧЕСКИХ И \\ ЮРЕДИЧЕСКИХ ЛИЦ В УКРАИНЕ
}

\section{ANALYSIS OF CHANGES IN THE INSTITUTIONAL MECHANISM OF TAXATION OF NATURAL PERSONS AND LEGAL ENTITIES IN UKRAINE}

\begin{abstract}
Стаття присвячена дослідженню змін інституційного механізму оподаткування фізичних та юридичних осіб в Україні. Автором було сформовано поняття «інституиійний механізм оподаткування фізичних та юридичних осіб» та здійснено трунтовний аналіз змін інститутів оподаткування, щео були або мають бути запроваджені у зв'язку з ситуацією, що склалася на сьогоднішній день в Україні (основна увага приділена змінам в оподаткуванні податком на прибуток, ПДВ, податком на доходи фізичних осіб та ресурсними платежами), досліджено місие Украӥни в міжнародних рейтингах за податковою складовою, виявлені тендениії в розвитку податкової системи України та надано прогноз ї̈ подальшого розташування в міжнародних рейтингах. За результатами проведеного дослідження автором було систематизовано зміни інститутів оподаткування та проведено комплексний аналіз перетворень інституційного механізму оподаткування фізичних та юридичних осіб. Таким чином, стаття має практичне значення для розвитку сфери оподаткування $i$ містить вдосконалення теоретичних розробок в галузі розвитку інституту оподаткування.
\end{abstract}

Ключові слова: податки; інституційний механізм оподаткування фізичних і юридичних осіб; інститути; податок на прибуток; податок на додану вартість; податок на доходи фізичних осіб.

Статья посвящена исследованию изменений институционального механизма налогообложения физических и юридических лии в Украине. Автором было сформировано понятие «институциональный механизм налогообложения физических и юридических лиц» и осуществлено анализ изменений институтов налогообложения, которые были или должны быть введены в связи с ситуацией, сложивщейся в Украине (основное внимание уделено изменениям в налогообложении налогом на прибыль, НДС, налогом на доходы физических лии и ресурсными платежами), исследовано место Украины в международных рейтингах по налоговой составляющей, выявлень тенденщии в развитии налоговой системь Украины и предоставлен прогноз дальнейшего ее расположения. По результатам проведенного исследования автором были систематизированы изменение институтов налогообложения и проведен комплексный анализ преобразований институционального механизма налогообложения физических и юридических лии. Таким образом, статья имеет практическое значение для развития сферы налогообложения и содержит усовершенствования теоретических разработок в области развития института налогообложения. 
Ключевые слова: налоги, институциональный механизм налогообложения физических и юридических лиц, институты, налог на прибыль, налог на добавленную стоимость, налог на доходы физических лиц.

The article investigates changes in the institutional mechanism of taxation of natural persons and legal entities in Ukraine. The author, based on research concepts "institution", «institutional mechanism» proposed by a number of specialists was formed concept of «institutional mechanism for taxation of individuals and entities» and performed a detailed analysis of changes in tax institutions that have been or are to be adopted in connection with situation today in Ukraine (main attention is paid to changes in income tax, VAT, tax on personal income and resource payments) investigated Ukraine's place in the international rankings for tax component, and further identified trends in tax system of Ukraine and forecast provided further location in the international rankings. The results of the research the author has been systematically changing the institutions of taxation and a comprehensive analysis of transformations institutional mechanism for taxation of individuals and entities. Thus, the paper is of practical importance for the development of taxation and contains improvements theoretical developments in the field of taxation institute.

Keywords: taxes, institutional mechanism for taxation of individuals and entities, institutions, income tax, value added tax, tax on personal income.

Вступ. Сучасні умови розвитку економічних відносин зумовили виникнення значного інтересу серед науковців та практиків до ролі інститутів в економічному зростанні, а також до розвитку інституційного середовища та формування інституційних механізмів реалізації господарської діяльності. Зважаючи на розмаїття зовнішнього i внутрішнього середовища функціонування суб'єктів господарювання, навколо кожного 3 них утворюється безліч як внутрішніх так і зовнішніх інститутів, які формують інституційне середовище. Інституційне середовище здійснює вплив на суб'єктів господарювання через різноманітні інституційні механізми (внутрішній інституційний механізм управління підприємства, ринковий інституційний механізм, інституційний механізм державного регулювання, інституційний механізм оподаткування тощо). В даному дослідженні основну увагу приділено зміні інституційного механізму оподаткування фізичних i юридичних осіб, оскільки саме податки являються одним з основних факторів впливу на ефективність діяльності суб'єктів господарювання i можуть виступати як рушійним механізмом так і відігравати стримуючу роль в їх розвитку. Крім цього, фіскальна функція податків дозволяе наповнювати державний бюджет, а дане питання зважаючи на ситуацію, яка склалася на сьогоднішній день в Україні, стоїть надзвичайно гостро. Дослідження, що проводяться міжнародними організаціям показують, що податкова система України $є$ надзвичайно неефективною, про що свідчать значний рівень податкового тиску, нестабільність податкового законодавства, високий відсоток ухиляння від сплати податків, прогалини в адмініструванні тощо. 
Звичайно, за умов орієнтації України на Євроінтеграцію, така ситуація в податковій сфері є недопустимою. Саме тому, постійна зміна інституційного механізму оподаткування, спрямована на пошук балансу між платниками податків і державою та узгодження їх інтересів в податковій сфері. Таким чином, питання дослідження змін механізму оподаткування фізичних i юридичних осіб є досить актуальним на сьогоднішній день.

Українські науковці мають певні здобутки в дослідженні системи оподаткування. Серед них можна відмітити наукові праці таких вчених, як: Ю. Б. Іванов [1], Н. В. Мельник [2], Л. Л. Тарангул [2], 3. С. Варналій [2], Петрович [3], Л. Б. Рябушка [4], Д. В. Веремчук [4] та інші. Що ж стосується розробки понять «інститут», «інституційний механізм», «інституційне середовище», то доцільно буде виділити таких вчених: Д. Норт $[5,6]$, Д. Комманс [8], К. Ерроу [9], Л. Абалкін [10] та інші. Однак, зважаючи на сучасні реалії в сфері оподаткування можна зробити висновок про те, що даний напрям дослідження потребує подальшого доопрацювання і розробки 3 метою удосконалення інституційного механізму оподаткування України i пошуку балансу інтересів платників податків та держави.

Постановка завдання. Метою даної статті є вдосконалення теоретичних розробок в галузі дослідження інституційного механізму оподаткування фізичних та юридичних осіб в Україні та проведення комплексного аналізу його змін. Відповідно до зазначеної мети, в роботі поставлено та вирішено наступні завдання:

- на основі дослідження понять «інститут», «інституційний механізм», запропонованих рядом спеціалістів, сформувати поняття «інституційний механізм оподаткування фізичних та юридичних осіб»;

- здійснити грунтовний аналіз змін інститутів оподаткування;

- дослідити місце України в міжнародних рейтингах за податковою складовою;

- виявити подальші тенденції в розвитку податкової системи України та надано прогноз іï подальшого розташування в міжнародних рейтингах.

Методологія. Теоретико-методологічну основу дослідження складають праці провідних вітчизняних та зарубіжних науковців. При проведені даного дослідження був використаний метод порівняльного аналізу, за допомогою якого проводиться порівняння нових інститутів оподаткування та тих, що існували раніше. На основі методу наукової абстракції 3 сукупності інституційних механізмів, що впливають на діяльність підприємства виділяється саме інституційних механізм оподаткування та виокремлюються найбільш вагомі його зміни в сплаті ПДВ та податку на доходи фізичних осіб. Також автором був використаний системний підхід та статистичний метод. 
Результати дослідження. Будь-який механізм 3 технічної точки зору (з грецької - машина) - система тіл, що призначена для перетворення руху одного або декількох тіл у потрібний рух інших тіл [11]. 3 економічного погляду, це послідовність станів, процесів, що визначають собою яку-небудь дію, явище [12]. 3 позиції управління, механізм є сукупністю засобів дії або комплексом важелів, використовуваних в управлінні; це сукупність мотивів діяльної активності персоналу, які визначають як саму можливість, так і ефективність управління, від яких залежить сприйняття дії [13, с. 290]. Переходячи до розгляду саме інституційного механізму коротко визначимо сутність категорії «інститут». Зважаючи на різноманітність підходів до визначення даної категорії, на нашу думку в даному дослідженні варто зупинитися на класичному, загальновизнаному визначенні запропонованому видатним представником інституціоналізму Д.Нортом. Так, на його думку інститути, будучи «правилами гри», задають систему стимулів, спрямовуючи діяльність людей у певному руслі, саме тому, коли люди вірять у справедливість i надійність законів, договорів i прав власності, вони утримуються від спроб шахрайства та крадіжок, що призводить до зниження трансакційних витрат. У складі інститутів Д. Норт виділяв: неформальні обмеження (звичаї, традиції); формальні обмеження (закони, нормативні акти тощо); механізм примусу, що забезпечує дотримання правил (міліція, суди тощо) [5]. Формальні та неформальні обмеження разом утворюють неперервний ряд правил від звичаїв та традицій з одного боку до конституцій i законів з іншого. Саме 3 такого набору інститутів формується інституційне середовище, а інституційні механізми є способом впливу на формування відповідного інституційного середовища в відповідній сфері, зокрема в податковій. Переходячи до дослідження інституційного механізму зазначимо, що вперше даний термін був застосований К. Поланьї [7], який визначає його для ринкової економіки через механізм обміну (взаємний, на натуральній основі). А вже Д. Комманс [8] вважав, що саме інституційний механізм надає змогу реалізовувати очікування шляхом визначення цінності (за винятком трансакційних витрат). Щодо К. Ерроу [9], то він інституційний механізм фактично ототожнював із механізмом розподілу ресурсів. Найбільш влучним, на нашу думку, є класичне визначення запропоноване Д. Нортом [6], у відповідності до якого інституційний механізм надає змогу забезпечувати як створення правил, так і відслідковувати наслідки їх застосування. Досить влучне визначення «інституційного механізму» надає Л.Абалкін [10]. В його працях інституційний механізм досліджується як особлива підсистема організаційно-економічних та тих відносин, які забезпечують суспільні взаємозв'язки. Відтак, до неї слід включати організаційний досвід, психологічний клімат, норми, правила, звички, традиції тощо. Тож, зважаючи 
на наведені вище визначення економічних категорій «інститут» та «інституційний механізм», можна вважати, що інституційний механізм оподаткування фізичних i юридичних осіб включає в себе сукупність інституційних важелів, стимулів і заходів спрямованих на встановлення формальних та неформальних обмежень i взаємозв'язків між ними, які функціонують у вигляді набору правил, що формують систему оподаткування та забезпечують узгодження та коригування інтересів суб'єктів господарювання та держави.

Інституційний механізм оподаткування фізичних та юридичних осіб включає:

- принципи, функції, завдання та мету функціонування механізму;

- безпосередньо самі податки (інструменти механізму);

- нормативно-правове забезпечення;

- суб'єкти та об'єкти механізму;

- методи організації, регулювання податкових відносин та управління ними, способи і порядок сплати податків.

Власне, принципи функціонування цього механізму $\epsilon$ принципами політики держави у сфері оподаткування фізичних і юридичних осіб, які прописані в Податковому кодексі України. Основними функціями інституційного механізму оподаткування $\epsilon$ : 1) забезпечення надходжень податків до бюджетів відповідних рівнів; 2) регулювання суспільноекономічних процесів за допомогою податків; 3) контроль за дотриманням податкового законодавства.

Виходячи 3 функцій інституційного механізму оподаткування можна стверджувати, що головною метою інституційного механізму оподаткування є створення інституційного середовища оподаткування фізичних і юридичних осіб, забезпечення його функціонування за допомогою виконання сукупності формальних i неформальних правил i норм. Головними завданнями інституційного механізму оподаткування $€$ створення оптимальних податкових інститутів, які не стримуватимуть розвиток суб'єктів господарювання, та забезпечуватимуть надходження до бюджету коштів, достатніх для задоволення державних потреб.

Суб’єктами інституційного механізму оподаткування слід вважати фізичних та юридичних осіб, що орієнтовані на визнання встановлених (формально/ неформально) обмежень, які визначають масштаби і напрямки, форми, засоби та методи реалізації податкової політики держави. Об'єктом інституційного механізму оподаткування може виступати безпосередньо те на, що нараховується податок і від чого залежить його розмір.

Формування та функціонування інституційного механізму спрямоване на створення стійких взаємозв'язків між суб'єктами господарювання та державою з приводу стягнення податків, що забезпечуються існуванням ряду 
правил i норм, яких мають дотримуватися обидві сторони. Тобто, функціонування інституційного механізму вимагає єдності і узгодженості дії зацікавлених сторін, тобто суб'єктів господарювання та держави. Поряд 3 цим, функціонування інституційного механізму вимагає постійного моніторингу правил i норм, дослідження їх впливу на суб'єктів інституційного механізму, а також їх оперативного корегування або скасування у разі, якщо цей вплив виявиться недостатньо ефективним. Таким чином, відносно постійними величинами в інституційному механізму оподаткування фізичних і юридичних осіб в Україні являються принципи, функції, завдання, мета, суб'єкт та об'єкт. Всі інші елементи зазнають постійних змін, що досить негативно впливає на суб'єктів даного механізму. Зміна будь якого 3 елементів інституційного механізму призводить до часткової зміни функціонування механізму в цілому. Тож, завданням даного дослідження $є$ аналіз змін інституційного механізму оподаткування фізичних $\mathrm{i}$ юридичних осіб в Україні.

Вагомі зміни в інституційному механізмі оподаткування відбулися після прийняття 2 грудня 2010 року Податкового кодексу України. Їх аналіз був проведений автором у попередніх дослідженнях $[14,15]$, тому лише коротко перерахуємо основні з них [16],:

1. Поступове зниження ставки податку на прибуток до $18 \%$ у 2014 році та скасування 4-ох груп основних засобів для нарахування амортизації в податковому обліку і відсотків по кожній з них.

2. 31 січня 2013 року введення податку на нерухоме майно, відмінне від земельної ділянки.

3. Скасування ряду місцевих податків, зокрема податку 3 реклами, комунального податку тощо, що слугували основними наповнювачами місцевих бюджетів.

4. Нововведенням $є$ застосування диференційованої ставки податку на доходи фізичних осіб (15\% або 17\%), що залежить від розміру отримуваної заробітної плати.

5. Кардинальних змін зазнала спрощена система оподаткування. ПКУ поділяє суб'єктів господарювання, що мають право обрати спрощену систему оподаткування на 6 груп, віднесення до яких залежить від розміру доходу $\mathrm{i}$ кількості працюючих. Вагомою зміною стало віднесення єдиного податку до числа місцевих, що дало змогу збільшити надходження до бюджетів даного рівня. В 2011 р. надходження від єдиного податку склали майже 2 млрд. грн., тобто близько $80 \%$ загального обсягу місцевих податків та зборів [17]. 


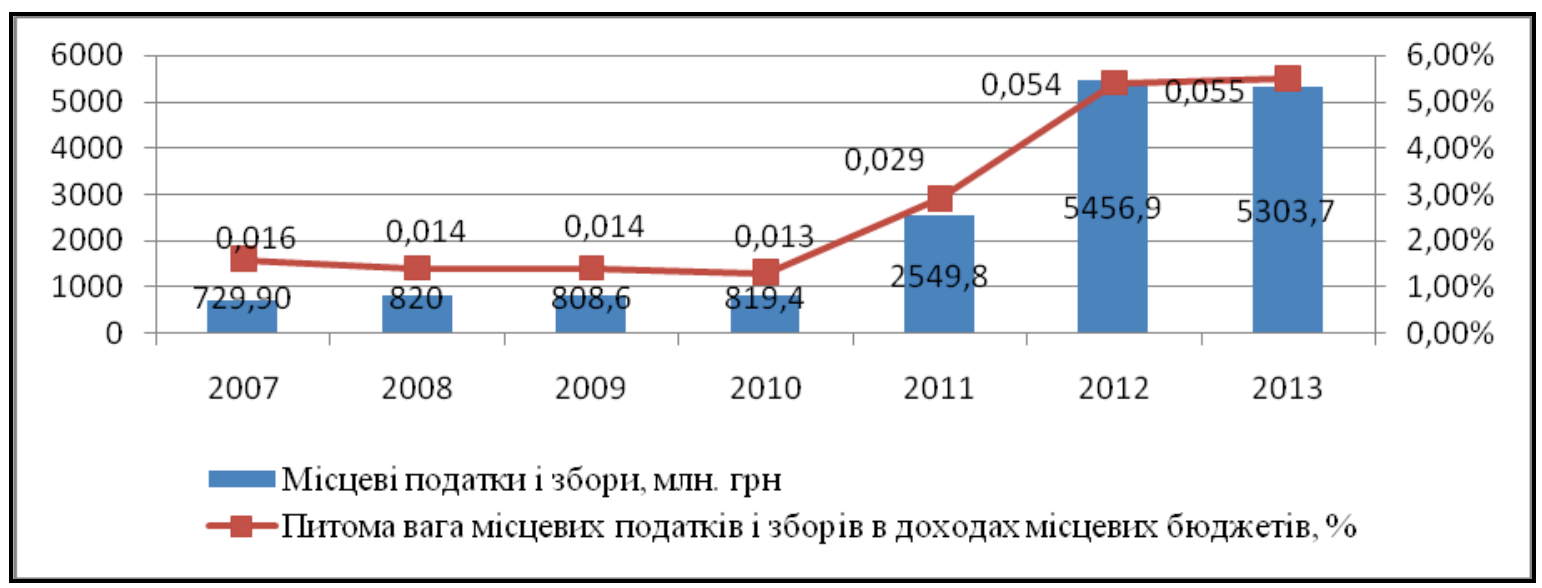

Рис. Динаміка надходжень місцевих податків і зборів до місцевих бюджетів України за 2007 - 2013 роки

Бачимо, що до введення в дію Податкового кодексу місцеві податки і збори формували 2-3 \% дохідної частини місцевих бюджетів (в країнах СС їхня частка формує в середньому $30 \%$ ). 3 рисунку видно суттєве зростання питомої ваги місцевих податків і зборів у доходах місцевих бюджетів, причиною таких змін стало переведення єдиного податку для суб'єктів малого підприємництва 3 категорії загальнодержавних до місцевих податків [17].

Загалом, спостерігаються позитивні тенденції розвитку податкової системи в Україні за період з 2001 по 2013 рік. Так, зокрема зростала кількість зареєстрованих платників податків - юридичних осіб i до 2011 p. зареєстрованих підприємців - громадян. За 2001 - 2012 рр. кількість платників - юридичних осіб, які перебували на обліку в органах ДПС, зросла на 20,3 \% і на початок 2013 р. склала майже 920 тис. осіб. За цей період кількість платників - фізичних осіб, які перебували на обліку в органах ДПС, зросла на $127,4 \%$ і на початок 2013 р. склала 2378,1 тис. осіб. Фактичне надходження до бюджету податків і платежів, що контролюються ДПС України, у 2012 р. зросло порівняно з 2001 р. більше, ніж у 6 разів, а фактичне надходження до бюджету відповідних платежів на одного зареєстрованого платника податків у 4,4 рази. 32001 р. кількість зареєстрованих платників податків - юридичних осіб, які сплачують податки, постійно зростала і у 2009 р. досягла 90,5\%. Звичайно, порівняно 3 показником 71 \% у 2001 р. відбулось істотне поліпшення, але той факт, що $з$ платників податків, взятих на податковий облік, кожний десятий податків не сплачує, викликає занепокоєння [18]. Проте, після прийняття Податкового кодексу ситуація по деяким напрямкам значно погіршилась. Так, у 2010 р. частка платників податків - юридичних осіб, які сплачують податки, у загальній кількості зареєстрованих платників податків - юридичних осіб, скоротилася до 83,3 \%. Така негативна тенденція продовжилась і в 2011 р., і в 2012 р. - відповідно до 82,1 \% і 80,5 \% [18]. 
Важливим фіскальним показником, який характеризує вплив податків на економіку країни в цілому чи на окремих суб'єктів господарювання $\epsilon$ податкове навантаження. Рівень податкового навантаження в Україні визначається за методикою запропонованою Світовим банком в рамках оцінки ведення бізнесу в різних країнах світу. Сплата податків є одним 39 індикаторів, що показують рівень регулювання підприємницької діяльності в країні, вони враховують час і вартість виконання підприємцем вимог держави щодо реєстрації нового підприємства і ведення його діяльності, здійснення торгівельних операцій, забезпечення виконання контрактів, оподаткування та закриття підприємства. Сам індикатор «Сплата податків» складається 3 трьох показників: кількість платежів протягом року; витрати часу на підготовку податкової звітності і сплату податків для трьох основних податків (ПДВ, податок на прибуток, внески на соціальне страхування); узагальнена ставка податку (таблиця 1).

Таблиця 1

Динаміка показників, що характеризують рівень розвитку податкової системи України [19]

\begin{tabular}{|c|c|c|c|c|}
\hline Рік & $\begin{array}{c}\text { Кількість } \\
\text { платежів на } \\
\text { рік }\end{array}$ & $\begin{array}{c}\text { Час для } \\
\text { сплати } \\
\text { податкових } \\
\text { платежів }\end{array}$ & $\begin{array}{c}\text { Сукупна } \\
\text { податкова } \\
\text { ставка (у } \\
\text { відсотках до } \\
\text { комерційного } \\
\text { прибутку) }\end{array}$ & $\begin{array}{c}\text { Місце України серед інших } \\
\text { країн світу за рівнем } \\
\text { розвитку податкової системи }\end{array}$ \\
\hline 2009 & 99 & 848 & 58,4 & 180 місце серед 181 країни \\
\hline 2010 & 147 & 736 & 57,2 & 181 місце серед 183 країн \\
\hline 2011 & 135 & 657 & 55,5 & 181 місце серед 183 країн \\
\hline 2012 & 135 & 657 & 57,1 & 181 місце серед 183 країн \\
\hline 2013 & 28 & 491 & 55,4 & 165 місце серед 185 країни \\
\hline 2014 & 28 & 390 & 54,9 & 164 місце серед 185 країни \\
\hline
\end{tabular}

* Для порівняння: середня сукупна податкова ставка у світі складає 44,8\% від комерційних прибутків, середня кількість податкових платежів за рік - 28,5, а середня кількість часу для здійснення цих платежів 277 годин на рік.

Кількість платежів суттєво зменшилась за рахунок скасування ряду місцевих податків. Експерти Світового банку відзначили, що скорочення часу стало можливим за рахунок спрощення декларацій для сплати ПДВ та єдиного соціального внеску, а також удосконалення системи електронного звітування. За оцінками дослідження, за останній рік податкова ставка в Україні знизилася з 55,4\% до 54,9\%, кількість платежів залишилася на рівні минулого року - 28 [20]. Станом на 2013 рік в Україні податкове навантаження на зарплату сягає 56\% (єдиний соціальний внесок у розмірі від 36,76 до 49,7\% плюс 15\% (17\%) податок з доходів фізичних осіб). У Німеччині відрахування з зарплати лише 30\%, а у Швеції, країні з одними із найвищих податків у світі, - 46\% [21]. 
Згідно $з$ дослідженням, за останні півроку - 3 жовтня 2013 року по червень 2014 року - інтегральний податковий індекс, який вимірюється фахівцями ЄБА (Європейська бізнес-асоціація) уже вп'яте, не зазнав істотних змін і становить 2,37 бала 3 п'яти можливих. При тому, що на початок жовтня 2013 року цей показник становив 2,41 бала 3 п'яти можливих [22]. Податковий індекс розраховується по таких компонентах, як: якість податкового законодавства, яке займає в структурі індексу $15 \%$; адміністрування податків $40 \%$; фіскальний тиск - 30\%; якість податкового обслуговування $-15 \%$. У результаті, близько 75\% учасників дослідження негативно оцінили якість податкового законодавства [22]. Близько 63\% респондентів відзначили, що податкова звітність була і залишається складною і незручною. Близько 48\% опитаних визнали, що тиск податкових органів і «пропозиції» сплатити податки авансом усе ще заважають діяльності [22]. Таким чином, несуттєве, проте все одно зниження показника Індексу свідчить про те, що настрої бізнесу істотно не змінилися і платники податків так само гостро відчувають певні вади системи оподаткування. Одержані дані повинні стати ще одним сигналом державним органам про те, що інституційний механізм оподаткування фізичних і юридичних осіб, який був сформований прийняттям Податкового кодексу виявився досить недосконалим. Саме тому, ми бачимо, що на протязі всього періоду його функціонування відбуваються постійні зміни інститутів, що забезпечують його роботу. На сьогоднішній день в розвиток податкової системи України вносить свої корективи досить не проста економічна і політична ситуація, що зумовлює необхідність корегування існуючих інститутів.

Так, урядом запропоновано розробити нову редакцію Податкового кодексу і впровадити в Україні до 2016 року нову систему оподаткування, яка в першу чергу передбачатиме скорочення базових податків до дев'яти. Виконання цього завдання дасть змогу спростити процедуру адміністрування збору податків. Крім цього на сьогоднішній день вже набула чинності низка змін до Податкового Кодексу України. Законом України «Про внесення змін до Податкового кодексу України та деяких інших законодавчих актів України» тимчасово, до 1 січня 2015 введено новий загальнодержавний збір військовий збір, який стягуватиметься за ставкою $1,5 \% 3$ доходів фізичних осіб [23]. Утримання військового збору з доходу фізичних здійснюється таким чином (ЗП - це нарахована заробітна плата):

ЄCВ $=3$ З грн. * 3,6\% ; ПДФО = (ЗП грн. - ССВ грн. - Соціальна пільга грн.) * 15\% , Військовий збір = ЗП грн. * 1,5\% Працівник отримує: ЗП - ССВ - ПДФО - Військовий збір.

До 1 січня 2015 року підвищена рента на видобуток залізної руди з 5\% до $8 \%$, нафти - з 39\% до 45\%, газу з покладів до 5 км - $328 \%$ до $55 \%$, газу 3 покладів понад 5 км - $315 \%$ до 28\% [23]. 
Крім того, з 2015 року збільшується «поріг» обов'язкової реєстрації підприємства платником ПДВ - 3300 тис. грн. до 1 млн. грн., та передбачається впровадження електронної системи адміністрування ПДВ, яка забезпечить перехід на оформлення податкових накладних лише в електронному вигляді, обов'язкову реєстрацію всіх без винятку податкових накладних і розрахунків коригування у Сдиному реєстрі, а також кардинальні зміни у системі бюджетного відшкодування ПДВ. Продовжено до 31 грудня 2014 року режим звільнення від оподаткування ПДВ операцій з експорту зернових і технічних культур; скасовано звільнення від оподаткування ПДВ операцій 3 поставки лісоматеріалів, паливної деревини, відходів лісопереробної промисловості.

Скасовано оподаткування за нульовою ставкою податку на послуги 3 перевезення пасажирів швидкісними поїздами Інтерсіті+ [23]. Скасовано звільнення від оподаткування прибутку, отриманого від: надання готельних послуг в готелях категорій «п'ять зірок», «чотири зірки» і «три зірки»; основної діяльності підприємств галузі, які виробляють електричну енергію виключно з поновлюваних джерел енергії. Скасовано пільгу оподаткування за зниженою ставкою (10\%) прибутку, отриманого від операцій із цінними паперами та деривативами. Доходи інвестиційних фондів у вигляді процентів підлягають оподаткуванню на загальних підставах.

Крім цього у відповідності до чинного Закону України «Про запобігання фінансової катастрофи та створення передумов для економічного зростання в Україні» [24] передбачено ще ряд змін до Податкового Кодексу та інших законодавчих актів. Зокрема, даний закон передбачає наступні зміни:

В розділі «Податок на прибуток» [24]:

1) Основна ставка податку на прибуток залишена на рівні $18 \%$, а іiі заплановане зниження в наступних роках до $16 \%$ скасовано.

В розділі «Податок на додану вартість» [24]:

1) Основна ставка ПДВ залишена на рівні $20 \%$, а іiі заплановане зниження в наступних роках до 17\% також скасовано;

2) Постачання лікарських засобів тепер не звільняється від ПДВ, а оподатковується за ставкою 7\%;

3) Граничну вартість товарів, що не оподатковуються ПДВ при переміщенні через митний кордон було збільшено зі 100 євро до 150 євро;

4) Граничну вартість товарів, що не оподатковуються ПДВ при ввезені за допомогою почтових чи експрес відправлень було зменшено з 300 євро до 150 євро.

«Податок на доходи фізичних осіб» [24]:

1) Пенсії будуть відноситись до загального оподаткованого доходу (та суми щомісячного довічного грошового утримання, що виплачується 3 
бюджету чи пенсійного фонду) та підлягають оподаткуванню, проте лише в сумі, що перевищує 10000 гривень на місяць.

2) До місячного оподаткованого доходу відносяться доходи у вигляді дивідендів, виграшів, призів, процентів (крім процентів у сумі, що не перевищує в рік сімнадцять прожиткових мінімумів для працездатної особи, встановлених законом на 1 січня звітного податкового року, процентів, що нараховані на цінні папери, емітовані центральним органом виконавчої влади та доходи у вигляді процентів на поточні банківські рахунки, за якими на користь фізичних осіб здійснюються виключно виплати стипендій, пенсій, соціальної допомоги та інших передбачених законом соціальних виплат; дивідендів, які нараховуються на користь платника податку у вигляді акцій (часток, паїв), емітованих юридичною особою - резидентом, що нараховує такі дивіденди, за умови, що таке нарахування жодним чином не змінює пропорцій (часток) участі всіх акціонерів (власників) у статутному фонді емітента, та в результаті якого збільшується статутний фонд емітента на сукупну номінальну вартість нарахованих дивідендів).

3) Проценти з банківських вкладів, та інші види пасивних доходів, такі як дивіденди, роялті, та дохід від інвестиційної діяльності підлягають оподаткуванню за наступною прогресивною шкалою:

- 15\% (застосовується до доходу, який не перевищує 204 прожиткові мінімуми на рік);

- 20\% (застосовується до перевищення попереднього порогу, проте яке не перевищує 396 прожиткові мінімуми на рік);

- 25\% (застосовується до перевищення попереднього порогу).

4) Дохід у вигляді процентів повинен включатись особою в річну декларацію про доходи. Банки зобов'язані повідомляти податкові органи про загальну суму процентів, сплачених своїм клієнтам. Наявність у банків обов'язку щодо утримання податку у розмірі $15 \% 3$ джерела виплати доходу підлягає подальшому уточненню, оскілки положення Закону стосовно цього $є$ досить нечіткими.

Інші податки і збори:

1) Збільшено ставки акцизного податку на різні види товарів, зокрема на спиртні напої (до 25\%), пиво (до 42,5\%), тютюнові вироби (до 25\%), нафтопродукти (включаючи паливні компоненти), автомобілі і мотоцикли.

2) Збільшено розмір мінімального податкового зобов'язання на тютюнові вироби.

3) Збільшено ставки збору за першу реєстрацію транспортного засобу, екологічного податку, збору за спеціальне користування води;

4) Зміни розміру податку на землю.

Від цих змін уряд планує отримати ресурс у 13,5 млрд. грн., зокрема: 3,3 млрд. грн. від оподаткування доходів 3 капіталу (за ставкою 15\%); 0,4 млрд. 
грн. від скасування пільг із ПДВ для окремих галузей; 0,3 млрд. грн. від збільшення акцизу; 2,9 млрд. грн. від запровадження тимчасового військового збору (1,5\% на фонд оплати праці); 1,8 млрд. грн. від подовження до 1 січня 2015 року режиму звільнення від сплати ПДВ операцій з експорту зерна.

Ще 6,2 млрд. грн. уряд планує отримати від збільшення плати за користування надрами для видобутку нафти і газу, проте ця ініціатива уряду дуже суперечлива, оскільки такі зміни можуть досить негативно відобразитися на розвитку галузі видобутку газу і нафти в Україні.

Висновки. Науковою новизною проведеного дослідження $\epsilon$ формування визначення «інституційного механізму оподаткування фізичних та юридичних осіб», а також визначення його функцій, завдань та мети. Так, інституційний механізм оподаткування фізичних i юридичних осіб включає в себе сукупність інституційних важелів, стимулів i заходів спрямованих на встановлення формальних та неформальних обмежень і взаємозв'язків між ними, які функціонують у вигляді набору правил, що формують систему оподаткування та забезпечують узгодження та коригування інтересів суб'єктів господарювання та держави. Інституційний механізм оподаткування фізичних та юридичних осіб включає: принципи, функції, завдання та мету функціонування механізму; безпосередньо самі податки (інструменти механізму); систему управління оподаткуванням (нормативно-правове забезпечення і суб'єкти та об’єкти механізму); методи організації, регулювання податкових відносин та управління ними, способи і порядок сплати податків. Автором визначені функції, завдання та мета інституційного механізму оподаткування фізичних і юридичних осіб та з'ясовано, що саме дані елементи, а також суб'єкт і об'єкт є відносно постійними елементами даного механізму, а всі інші елементи зазнають постійних змін. Практичне значення даного дослідження полягає в детальному аналізі змінних елементів механізму оподаткування. Таким чином, тимчасові та постійні зміни інституційного механізму оподаткування фізичних та юридичних осіб можна оцінювати як вимушені заходи, які спрямовані на стабілізацію ситуації в країні, можуть призвести до збільшення податкового тиску і рівня сукупної податкової ставки в країні і відповідно ще більшого падіння України в міжнародних рейтингах. Однак, позитивним моментом $\epsilon$ поступове зменшення значної кількості податків, що заплановано з 2016 року. Отже, аналіз змін інституційного механізму оподаткування фізичних та юридичних осіб дозволив встановити ряд змін в інститутах оподаткування i взаємозв'язках між ними, а також оцінити рівень розвитку інститутів оподаткування на основі міжнародних рейтингів. Однак, на сьогоднішній день надавати рекомендації з даного питання не доцільно, оскільки більшість змін носять тимчасовий характер. Крім цього урядом України була оприлюднена «Концепція реформування податкової системи України», яка містить ряд 
суттєвих реформ спрямованих на лібералізацію податкової системи. Впровадження даних заходів дасть змогу Україні спростити процедуру сплати податків, знизити податковий тиск та піднятися в міжнародному рейтингу Doing Business. Проте, до впровадження запропонованих урядом, на перший погляд, досить прогресивних новацій фізичним i юридичним особам платникам податків доведеться впоратися зі складними податковими реаліями.

\section{Література:}

1. Іванов Ю. Б. Функції податків та податкове регулювання / Іванов Ю. Б. // Формування ринкової економіки в Україні: Науковий журнал. - 2009. - № 19. - С. 36 43.

2. Мельник Н. В. Податкова політика України: стан, проблеми та перспективи : монографія / Мельник Н. В., Тарангул Л. Л., Варналій 3. С. - К. : Вид-во «Знання України», 2008. - 675 с.

3. Петрович Й. Проблеми розвитку та шляхи вдосконалення податкової політики України / Петрович Й. // Банківська справа : зб. наук. Праць. - К. - 2008. - № 6. - С. 43 49.

4. Рябушка Л. Б. Бюджетно-податкова політика i в системі регулювання економічного розвитку держави / Л. Б. Рябушка, Д. В. Веремчук // Вісник Сумського державного університету : зб. наук. праць. - Суми : Вид-во СумДУ. - 2008. - № 3. - С. $182-$ 187.

5. Норт Д. Інституції, інституціональна зміна та функціонування економіки / Норт Д. ; [пер. з англ. І. Дзюб]. - К. : Основи, 2000. - 189 с.

6. Норт Д. Институты, институциональные изменения и функционирование экономики / Норт Д.; Пер. с англ. А. Н. Нестеренко; предисл. и науч. ред. Б. З. Мильнера. М. : Фонд экономической книги «Начала», 1997. - 188 с.

7. Поланьи К. Экономика как институционально оформленный процесс / Поланьи К. // Экономическая социология. - 2001. - Т. 3. - № 2, - С. 68-73.

8. Commons J. R. Institutional Economics / Commons J. R. // American Economic Review. - 1931. - V.21. - P. $648-657$.

9. Кеннет Дж. Эрроу Возможности и пределы рынка как механизма распределения ресурсов / Дж. Эрроу Кеннет // Теория и история экономических социальных институтов и систем. - М. - 1993. - С. 59.

10. Абалкин Л. И. Логика экономического роста / Абалкин Л. И. - М. : Институт экономики РАН, 2002. $-228 \mathrm{c}$.

11. Справочник - энциклопедия. [Електронний ресурс]. - Режим доступу: http:// www.navoprosotveta.net/14/14_3023.htm

12. Краткий экономический словарь / [ под ред. А. Н. Азрилиян ] . - М. : Институт новой экономики, 2001. - 1088 с .

13. Менеджмент персоналу / [ В. М. Данюк, В .М.Петюх, С. О. Цимбалюк та ін. ] ; за заг . ред. В. М. Данюка, В. М. Петюха . - К. : КНЕУ, 2004. - 398с.

14. Гречко А. В. Оцінка результатів впровадження податкового кодексу України / А. В. Гречко// Часопис економічних реформ / науково-виробничий журнал. - Луганськ. 2013. - № 3(11). - C. $35-42$.

15. Гречко А. В. Дослідження впливу податкового фактору на діяльність малих підприємств в Україні / А. В. Гречко// Бізнес-інформ. - 2013. - №10. - С. 336 - 342. 
16. Податковий кодекс України. Відомості Верховної Ради України. [Електронний ресурс] : документ 2755-17, редакція від 04.09.2014 року. - Режим доступу : www.rada.gov.ua.

17. Капустян Я. В. Роль місцевих податків і зборів у формуванні доходів місцевих бюджетів в умовах зміни податкового законодавства. Фінансові аспекти розвитку економіки: теорія, методологія, практика: матеріали Міжнародної науково-практичної конференції (Львів, 28-29 березня 2014 року) / ГО «Львівська економічна фундація». У 3-х частинах. - Львів : ЛЕФ, 2014. - Ч. 3. - С. 91 - 94.

18. Воронкова О. М. Сучасний стан сплати податків в Україні / Воронкова О. М. // Вісник ЖДТУ. - 2013. - № 4 (66). - С. 155 - 161.

19. РWC офіційний сайт. [Електронний ресурс]. - Режим доступу : http://www.pwc.com/gx/en/paying-taxes/index.jhtml

20. [Електронний ресурс]. http://www.finsettings.com/novini/4431-bznes-v-ukrayin-stav-vitrachati-menshe-chasu-na-splatupodatkv-ta-eksportno-mportn-operacyi-svtoviy-bank.html

21. В Україні з зарплати беруть більше податків, ніж у Швеції [Електронний ресурс] : Газета «Високий Замок», 22 січня 2013 року. - Режим доступу : http://www.wz.lviv.ua/news/26001

22. Бізнес в Україні продовжує відчувати тиск податкових органів [Електронний pecypc]. - Режим доступу : http://yurincom.com/ua/legal_news/B-znes-v-Ukrain--prodovzhuiev-dchuvati-tisk-podatkovih-organ-v--publication/

23. Закон України «Про внесення змін до Податкового кодексу України та деяких інших законодавчих актів України щодо усунення окремих неузгодженостей норм законодавства [Електронний ресурс] : документ 1200-18 редакція від 02.08.2014 року. Режим доступу : www.rada.gov.ua.

24. Закон України «Про запобігання фінансової катастрофи та створення передумов для економічного зростання в Україні» [Електронний ресурс] : документ 1166-18. Редакція від 02.08.2014 року. - Режим доступу : www.rada.gov.ua. 